\title{
INTRODUCING PUBLICITY RIGHTS? BREACH OF CONFIDENCE, THE PHOTOGRAPH AND COMMODIFYING THE IMAGE
}

\author{
Ronan Deazley, Lecturer in Law, University of Durham \\ INTRODUCTION
}

At the end of the 1970s Sophie Calle began to follow strangers through the streets of Paris, for no other reason than the pleasure of following them. She took photographs of them without their knowledge and kept a record of their movements until she lost sight of her subjects. On one occasion, in January 1981, having followed a man in the streets of Paris for a few minutes before he was lost to her in a crowd, she met the same man, by chance, later that evening at a Gallery opening. During the course of their conversation he informed her of an imminent trip that he was planning to Venice. Calle decided to follow him to Venice where, over nine days, she secretly compiled a written and visual record of his movements. Her accounts of these clandestine pursuits are presented in Double Game published for the first time in English by Violette Editions in $1999 .{ }^{1}$ In the same year, Phaidon Press published the work L'Autre incorporating a series of 90 photographs taken by Luc Delahaye of people, unknown to him, travelling the Paris metro. Between 1995 and 1997 Delahaye travelled the metro using a hidden camera to take portraits of numerous passengers sitting opposite him, the camera shutter snapping open and shut in time with the doors of the metro train. ${ }^{2}$ In Calle's photographs her subjects are generally seen from behind, from a distance, blurred, indistinct. They are anonymous individuals engaged in the ordinary and the everyday. She records them making purchases, stopping to talk with friends, eating in a restaurant, making their way home, a voyeur of the commonplace. They provide truthful if banal records of random, different and indifferent lives. By contrast, with Delahaye's portraits one is struck by a disturbing pervading similarity. Each of them refusing to engage with the person sitting opposite them on the metro, all of Delahaye's subjects stare into a similar middle-distant emptiness. For Delahaye the portraits capture a violence in his subjects' calm (perhaps inevitable) indifference to the urban condition.

Both Calle and Delahaye deal in images of others who are unknown and unknowing. None of them have any relationship with their subject other than through the lens of the camera. Neither, however, are any of their subjects aware of the fact that they are being photographed. Their work raises

1 Sophie Calle, Double Game (Violette, London, 1999).

2 Luc Delahaye, L'Autre (Phaidon, London, 1999). Delahaye's approach was not a new one. Between 1938 and 1941 Walker Evans, the renowned American photographer, had taken a similar series of images, travelling the New York subway, with a camera concealed under his coat. The images he captured were exhibited in 1966 at the New York Museum of Modern Art, as well as being published as a collection entitled Many Are Called (Houghton Mifflin, Boston, 1966). 
fundamental questions concerning the extent to which we can, or should be able to, control the public dissemination of our own image or likeness. Much has been written of late concerning the developments within the law of confidence and the emergence of an identifiable right to privacy, in the wake of the implementation of the Human Rights Act 1998. ${ }^{3}$ This article takes as its particular focus within that broader debate the photographic image; the suggestion here is that a number of recent decisions, concerning the publication of unauthorised and surreptitiously taken images, have seen the law of confidentiality develop in a manner approaching an informal recognition of de facto image rights. ${ }^{4}$ Moreover, within this general movement there are embryonic indications that the courts' direction allows for, not just the development of a relatively robust right of privacy pertaining to the image, but also for significant rights of publicity as well.

\section{The Development Of Breach Of Confidence}

The modern law of breach of confidence is generally traced back to the decision of Prince Albert v Strange ${ }^{5}$ which concerned a series of engravings that Prince Albert and Queen Victoria had made of each other for their own private enjoyment and consumption. ${ }^{6}$ Despite the fact that the etchings were generally kept under lock and key in the Royal household, William Strange, a printer in Paternoster Row, managed to acquire copies and reproduced them in a volume entitled A Descriptive Catalogue of the Royal Victoria and Albert Gallery of Etchings. Prince Albert brought an action before the courts seeking an injunction to prevent the exhibition, publication and sale of the etchings. Granting the injunction, Knight Bruce V-C commented that "the common law ... shelters the privacy and seclusion of thoughts or sentiments committed to writing, and desired by the author to remain not generally known."7 The same principle he considered extended to the visual image.

3 See for example: Rabinder Singh and James Strachan, "The Right to Privacy in English Law" [2002] EHRLR 129; I. Hare, "Vertically Challenged: Private Parties, Privacy and the Human Rights Act” [2001] EHRLR 526; Gavin Phillipson and Helen Fenwick, "Breach of Confidence as a Privacy Remedy in the Human Rights Act Era" [2000] MLR 660.

4 Duncan Lamont, a media partner at Charles Russell, recently commented upon the drift "towards the French situation where identifiable members of a Parisian crowd celebrating France's World Cup win of 1998 were able to obtain compensation from publishers of French newspapers reporting on a huge story"; see 'No snap judgments', The Guardian, 12 August 2002.

5 Prince Albert v Strange (1849) 2 De G. \& SM 652.

6 For a discussion of the development of the action in the early eighteenth century, see G Hammond, "The Origins of the Equitable Duty of Confidence" (1979) 8 Anglo-American Law Review 223.

7 The Vice Chancellor was influenced in his opinion by an orthodox, although erroneous, reading of Donaldson v Becket (1774) regarding the existence of a common law copyright in an author's unpublished manuscript. He commented as follows: "Upon the principle, therefore, of protecting property, it is that the common law ... shelters the privacy and seclusion of thoughts and sentiments committed to writing, and desired by the author to remain not generally known ... Such then being, as I believe, the nature and foundation of the common law as to manuscripts. . . its operation cannot of necessity be confined to literary subjects ... To consider, then the case of mechanical works, or works of art, executed by a man for his private amusement or private use; whatever protection these, or some of 
The actions of the printer amounted to "a breach of trust" and "a violation of confidence" and so should be curtailed.

The same cause of action extended equally well to photographs as it did to engravings. In Pollard $\mathrm{v}$ Photographic Company 8 the claimant, Mrs Pollard, sat for a portrait taken by the Photographic Company, after which the defendant company, without her permission, began to sell Christmas cards bearing her image. In court she sought an injunction to prevent the company selling or exhibiting any more of the cards. Granting her relief, North J commented that "the customer who sits for the negative thus puts the power of reproducing the object in the hands of the photographer; and the photographer who uses the negative to produce other copies for his own use, without authority, is abusing the power confidentially placed in his hands." It is "a gross breach of faith", he continued "when a lady's feelings are shocked by finding that the photographer she has employed to take her likeness . . . is publicly exhibiting and selling copies thereof."

Megarry $\mathrm{J}$, in Coco v Clark $^{10}$ gave formal structure to this common law offence, identifying a number of essential criteria that a claimant needed to satisfy before he or she could establish an actionable breach. He considered that:

(i) the information must have the necessary quality of confidence about it;

(ii) the information must have been imparted in circumstances importing an obligation of confidence;

(iii) there must be unauthorized use of the information to the detriment of the party communicating it.

We can appreciate that the claimant in Pollard would satisfy Megarry J's criteria, but consider the hypothetical situation in which someone surreptitiously takes a picture of an individual, in public, and later displays it on a gallery wall, or includes it in a published collection of his or her work? Could that person take an action against the photographer based upon breach of confidence? All three legs of the action as defined in Coco would seem to militate against that possibility; however, in light of recent developments, bringing a successful action no longer seems entirely implausible. Consider each of these criteria, in reverse order.

\section{(i) Unauthorised use of the information to the detriment of the claimant}

Whether there has been unauthorised use of the information will depend upon the scope of the obligation owed by one party to the other. When considering any form of personal information or private confidence it is

these, may have by an Act of Parliament, they are not, I apprehend, deserted by the common law"; supra n 5, at 695-96. However, for a reassessment of Donaldson and the notion that there existed a copyright at common law, see R.Deazley, "The Myth of Copyright at Common Law", CLJ March (2003) (106).

8 (1889) 40 Ch D 345.

9 Ibid. Similarly, see Stedall v Houghton (1901) 18 TLR 126.

10 [1969] RPC 41. For a more recent restatement of the continued relevance of these three criteria see Campbell v MGN Ltd [2002] EMLR 30. 
generally accepted that a person under an obligation of confidence makes unauthorised use of the information by simply disclosing it to a third party. ${ }^{11}$ Whether the claimant must still demonstrate that the disclosure of the information has caused them harm remains a moot point. ${ }^{12}$ In $X$ Health Authority $\mathrm{v} Y^{13}$ in which a hospital employee disclosed personal information pertaining to two colleagues in work, Rose $\mathrm{J}$ commented that, in the circumstances, "detriment in the use of the information [was] not a necessary precondition" of liability. ${ }^{14}$ For Rose J, detriment had occurred simply because the information had been leaked, not because it necessarily caused the claimant any direct harm. In relation to the hypothetical action outlined above, this aspect of the three-strand Coco test would seem relatively easy to satisfy.

\section{(ii) The information is imparted in circumstances importing an obligation of confidence}

Traditionally, under this branch of the Coco test, two elements had to be satisfied before the obligation of confidence would arise. The first of these related to the existence of an intimate or confidential relationship between the two parties involved. The second element involved the finding of an agreement of confidentiality between those two parties, that is, that the information that passed between them was understood to be of a confidential nature. Relationships such as those between doctor and patient, ${ }^{15}$ pharmacist and customer, ${ }^{16}$ and employer and employee, ${ }^{17}$ typically gave rise to such obligations of confidence. This leg of the Coco test has similarly undergone some transformation; ${ }^{18}$ it has been made plain by the courts that they will not require the existence of a formal relationship of confidentiality before the action for breach of confidence will bite. In Attorney General v Guardian

11 See for example $R$ v Department of Health, ex parte Source Informatics [2001] QB 424, at 440, in which Simon Brown LJ set out that, when dealing with such information " $[t]$ he concern of the law here is to protect the confider's personal privacy." In this case, the action of pharmacists in disclosing anonymised information relating to their customers' prescriptions to a company who then sold the information to pharmaceutical companies for marketing purposes, was not considered to breach their customers' confidentiality, as their privacy had not been invaded, but rather had been safeguarded.

12 In Attorney General v Guardian Newspapers (No.2) [1990] 1 AC 109, at 281-82 Lord Goff, in restating the general principles relating to the breach of confidence action, considered that it was appropriate "to keep open the question whether detriment to the plaintiff is an essential ingredient . . Obviously, detriment or potential detriment to the plaintiff will nearly always form part of his case; but this may not always be necessary."

13 [1988] 2 All ER 648.

14 Ibid, at 657.

15 W v Edgell [1990] Ch 59.

$16 R \mathrm{v}$ Department of Health, ex parte Source Informatics [2001] QB 424.

17 Attorney General v Guardian Newspapers [1987] 1 WLR 1248.

18 In Douglas v Hello! Ltd [2001] QB 967, at 1012 Keene LJ remarked that "already before the coming into force of the Act there [had] been persuasive dicta. . . to the effect that a pre-existing confidential relationship between the parties is not required for a breach of confidence." 
Newspapers $(\text { No.2 })^{19}$ Lord Goff, discussing the general principles underpinning this area of the law, observed that:

"[A] duty of confidence arises when confidential information comes to the knowledge of a person (the confidant) in circumstances where he has notice, or is held to have agreed, that the information is confidential, with the effect that it would be just in all the circumstances that he should be precluded from disclosing the information to others ... [which situations would include] where an obviously confidential document is wafted by an electric fan out of a window into a crowded street, or where an obviously confidential document, such as a private diary, is dropped in a public place, and then picked up by a passer-by." 20

A number of subsequent decisions, involving photography, operate in the same way, confirming that an identifiable communication between the two parties is no longer considered a necessary ingredient of a successful claim. ${ }^{21}$ In all of this, Phillipson and Fenwick observe a general shift in emphasis away from the need to find a mutual agreement as to the nature of the information as between the two parties, to a reasonable man test. ${ }^{22}$ That is, if the reasonable man, in the shoes of the defendant, would assume that an obligation of confidence arose then one would in fact exist. Such an approach was recently endorsed by Lord Woolf $C J$ in $A$ v $B \& C^{23}$ when he found that "[a] duty of confidence will arise whenever the party subject to the duty is in a situation where he either knows or ought to know that the other person can reasonably expect his privacy to be protected."24 Would the

9 [1990] AC 109.

20 Ibid, at 281.

21 Shelley Films v Rex Features [1994] EMLR 134; Hellewell v Chief Constable of Derbyshire [1995] 1 WLR 804; Creation Records v News Group [1997] EMLR 444.

22 Supra n 3. Simon Brown LJ, in ex p Source Informatics [2001] QB 424, at 439, commented that the appropriate question to ask, in the circumstances of that case, was "would a reasonable pharmacist's conscience be troubled by the proposed use to be made of the patients' prescriptions? Would he think that by entering Source's scheme he was breaking his customers' confidence, making unconscientious use of the information they provide?"

23 [2002] EMLR 371.

24 In Venables v News Group Newspapers [2001] EMLR 10, a decision concerning information about Robert Thompson and Jon Venables, the children responsible for the murder of Jamie Bulger, Butler-Sloss P pushed the boundaries of the law even further back, granting injunctions against the press restraining the disclosure of information about the claimants relating to their (i) present physical appearance, (ii) their new identities and whereabouts, (iii) their existing placements, and (iv) their time spent in secure units prior to August 2000. Recognising that she was being asked to extend the remit of the domestic law of confidence, Butler-Sloss P considered that the court had the authority to do so, where not to do so would be likely to lead to serious physical injury, or even death, of the applicant and there was no other way of protecting the applicant other than by granting the relief sought. She considered that "a duty of confidence could arise in equity independently of a transaction or relationship between the parties", a dictum which has been subsequently approved in Mills v News Group Newspapers [2001] EMLR 41. Butler-Sloss $\mathbf{P}$ did make clear however that "the extension of the law in 
reasonable person understand that his taking an unsolicited photograph of a stranger in public would be an unwarranted invasion of that stranger's privacy? In relation to the limits of such a reasonable man test, a recent decision of the Press Complaints Commission (the PCC) proves of some interest. ${ }^{25}$ In Tunbridge v Dorking Advertiser ${ }^{26} \mathrm{Mr}$ Tunbridge complained about an article in the Dorking Advertiser that included a photograph of him taken without his consent. ${ }^{27}$ This, he contended, amounted to a breach of clause 4 of the PCC's Code of Practice which provides that journalists and photographers "must not photograph individuals in private places." 28 A "private place" is defined within the Code as "public or private property where there is a reasonable expectation of privacy." 29 Mr Tunbridge had been photographed, with a companion, in a local café. The newspaper contended that the restaurant was a public place and therefore the complainant had no reasonable expectation of privacy. The Commission rejected the argument; it considered that "there may be places such as hotels which are accessible to the public where an individual will still have a reasonable expectation of privacy." "[C]ustomers of a quiet café", it continued, "could expect to sit inside such an establishment without having to worry that surreptitious photographs would be taken of them and published in newspapers." The claimant and his companion, it was concluded, "were clearly in a place where they had a reasonable expectation of privacy."

The position of the PCC in Tunbridge can be contrasted with their earlier determination concerning the complaint of Geoffrey Peck. In August 1995 the claimant, then suffering from depression, was caught on a CCTV surveillance system operated by the local council in Brentwood, Essex. Mr Peck was recorded walking alone at night through Brentwood city centre with a kitchen knife in his hand, having attempted suicide by cutting his wrists. The police were alerted, arrived on the scene and, after administering medical assistance, brought him to the police station where he was detained under the Mental Health Act 1983. He was subsequently examined and treated by a doctor and then released without charge. Thereafter, the council issued a number of press releases, including two stills from the footage taken of the claimant, in which he was identifiable, to highlight the benefits of the partnership between the council's CCTV system and the police. The story

confidence, by the grant of relief in the exceptional circumstances of this case" was unlikely to open the door "to the granting of general restrictions upon the media in cases where anonymity would be desirable" and doubted "whether it would be appropriate to grant injunctions to restrict the Press in this case if only Article 8 were likely to be breached."

25 S 12(4)(b) of the Human Rights Act 1998 sets out that the courts, when considering whether or not to grant any relief that would interfere with the right to freedom of expression, must "have particular regard to", amongst other things, "any relevant privacy code", which of course extends to the Code of Practice as applied and interpreted by the Commission.

26 (2002); a summary of the decision can be found online at http://www. pcc.org.uk/reports/latestdetails.asp?id=323.

27 "Skullduggery over a butterscotch tart", Dorking Advertiser 22 February 2002.

28 The PCC's Code of Practice is available online at http://www. pcc.org.uk/cop/cop.asp.

29 Ibid, clause 3. 
was taken up by two local papers, then in a local broadcast by Anglia Television, and finally by the BBC's Crime Beat, a programme that reached in excess of 9 million viewers. At the same time as applying, unsuccessfully, for leave to judicially review the council's decision to make public the CCTV footage in question, Peck complained to the PCC. Rejecting the complaint, the PCC did not consider that there had been a breach of the claimant's privacy within the meaning of their Code of Practice, given that the events in question had taken place in a town high street, open to public view. ${ }^{30}$ This then, in the PCC's view at least, seemed to represent the high water mark as to when and where photographers should consider that their actions were likely to represent an unwarranted invasion of an individual's privacy. Capturing the actions of a private individual in an unquestionably public space would seem to be acceptable.

Mr. Peck, however, appealed to the European Court of Human Rights in relation to both the disclosure by the council of the footage, as well as its publication and subsequent broadcast, arguing that the State had failed to fulfil its positive obligation to protect his private life in making no effective domestic remedy available to him. The Court, considering that his case raised "serious issues" under both Articles 8 and 13, declared the application admissible. The UK government submitted that "the incident in question did not form part of [Mr Peck's] private life given the substance of what was filmed and the location and circumstances of the filming." As a result, the government suggested, the applicant's right to private life had not been engaged at all. By contrast, Peck maintained that the fact that the event had been captured in a public place "was only one element in the overall assessment of whether there was an interference with [his] private life." ${ }^{31}$ Recalling the decisions of the Commission in Lupker $\mathrm{v}$ the Netherlands $(1992)^{32}$ and Friedl v Austria $(1995)^{33}$ the Court noted that there exists a

30 The Broadcasting Standards Commission (BSC) had previously upheld Mr Peck's complaint that the BBC had embarked upon an unwarranted infringement of his privacy (13 June 1997). Similarly, the Independent Television Commission (ITC) upheld Peck's complaint against Anglia Television.

31 Other factors to take into account were the fact that: it was late at night; he was not taking part in a public demonstration; his psychological state; he was unaware of being filmed; the disclosure took place without his knowledge or consent; the later use of the footage; and the extent to which it was made available to the public.

32 Unreported, no. 18395/91, 7 December 1992.

33 Judgment of 31 January 1995, series A no. 305-B. In Friedl the applicant alleged that the actions of the Austrian police in taking his photograph while he was participating in a public protest that he had organized with other persons, amounted to a breach of his right to respect for private life under art 8 of the Convention. The Austrian government, between the delivery of the opinion of the Commission, and the hearing before the Court, reached a settlement with the applicant, whereupon the Court struck the case out. When the Commission delivered its opinion, drawing upon the decision of the Court in Niemietz v Germany, judgment of 16 December 1992, series A no. 251-B, it made reference to the fact that "the notion of "private life" is not limited to the "inner circle" in which the individual may live his own personal life" but also comprised "to a certain degree the right to establish and develop relationships with other human beings and the outside word." However, taking note of the fact that "the photographs related to a public incident, namely a manifestation of several persons in a public place, in which the applicant was voluntarily taking part" as well as the 
"zone of interaction of a person with others, even in a public context, which may fall within the scope of "private life."” In this case, given that Peck was not in the street "for the purposes of participating in any public event" nor was he "a public figure", the Court considered that "the relevant moment was viewed to an extent which far exceeded any exposure to a passer-by . . . and to a degree surpassing that which the applicant could possibly have foreseen when he walked in Brentwood on 20 August 1995." As a result it was held that the disclosure of the footage by the Council constituted a serious interference with Peck's right to respect for his private life under Article 8. ${ }^{34}$

If the approach of the PCC in Tunbridge and the decision of the European Court in Peck do nothing else, they do at least indicate that, ultimately, there can be no bright line test for determining where the distinctions between public and private life are to be drawn, or when tests concerning reasonable expectations of privacy will be satisfied. If a photographer should assume that I have a reasonable expectation of privacy in a café, or walking home through an empty town centre late at night, giving rise to an obligation of confidence, can I have similar expectations in an art gallery, at the supermarket, or sitting in a carriage on the train? ${ }^{35}$ What if I am walking to my car in the grounds of a hospital, or sitting in a public park? The point is, the simple fact that a claimant has been captured on film in a public place does not necessarily mean that he will not be able to satisfy the second of the three criteria set out in Coco.

\section{(iii) The information has the necessary quality of confidence about it}

Presume, for the sake of argument, the scenario is such that the reasonable person would import an obligation of confidence between the photographer and his subject. Before the claimant can succeed in his action, he must also demonstrate that the photograph in question has the necessary quality of confidence about it. ${ }^{36}$ What is and what is not confidential information remains a matter of some conjecture, especially in relation to personal

fact that "they were taken solely for the purposes ... of recording the character of the manifestation of the actual situation at the place in question [and of] the conduct of the participants", the Commission considered that the taking of the photographs and their retention by the police for a limited period, did not amount to an interference with the applicant's private life under art 8 . Despite the unanimous opinion of the Commission in this case, Feldman writes that the approach adopted does at least make clear "that people carry privacy-related rights into the public domain, but permits them to be limited by reference to the nature of their activities and the related responsibilities of the state agencies"; David Feldman, "The Developing Scope of Article 8 of the European Convention on Human Rights" [1997] EHRLR 265, at 272.

34 Peck v United Kingdom, application no. 44647/98, 28 January 2003.

35 In this regard, it is of some interest that a recent application has been made to the European Court on behalf of the eldest daughter of Prince Ranier of Monaco, concerning the publication, in a number of German magazines, of photographs of her, her children and her companion, going about their daily lives; see Von Hannover (No 59320/00).

36 Where the information is useless or of a trivial nature, the duty of confidence will not apply; Attorney General v Guardian Newspapers (No.2) [1990] 1 AC 109, at 282 per Lord Goff. 
information. $^{37}$ In Douglas v Hello!, which concerned the publication of unauthorised photographs of the wedding of Michael Douglas to Catherine Zeta-Jones, counsel for the defence suggested that the photographs in issue did not really qualify as "information". Sedley LJ, however, dismissed the argument as "plainly wrong", continuing that "[t]he offending photographs convey the simple information: "This is what the wedding and the happy couple look like." "38 As to the appropriate test to apply when determining whether certain information does indeed carry the mark of confidentiality, in $A \vee B$ and $C$, Lord Woolf proffered that "usually the answer to the question whether there exists a private interest worthy of protection will be obvious." 39 In the same decision he referred to the case of Australian Broadcasting Corporation v Lenah Game Meats Pty Ltd, in which Gleeson CJ had indicated that " $[\mathrm{t}]$ he requirement that disclosure or observation of information or conduct would be highly offensive to a reasonable person of ordinary sensibilities is in many respects a useful practical test of what is private." 40 Both the comments of Lord Woolf and those of Gleeson CJ have received subsequent endorsement by Lord Phillips MR and the Court of Appeal in Campbell $\mathrm{v}$ MGN Ltd. ${ }^{41}$ That any given photograph may or may not satisfy either of these tests, and so attract the necessary badge of confidentiality, is not however the main problem here. The problem lies in the fact that, with the snap shot of the individual sitting in a restaurant or on a bus, arguably that individual has already chosen to make the relevant image (that is, the confidential information), freely accessible to all others who happen to come across him during the course of the day. In short, an image of his face cannot be of a confidential nature if he has chosen to make a public display of that face. The information under consideration is already in the public domain, and if it is already in the public domain then how can it be considered to be confidential? ${ }^{42}$ The initial reaction is to deny that the photograph of an individual in public can have anything in the way of confidentiality about it. However, again, a number of recent decisions begin to call this position into question.

37 In Duchess of Argyll v Duke of Argyll [1967] Ch. 302, the plaintiff was able to prevent her husband from publishing information concerning her private life, personal affairs and private conduct in breach of an obligation of marital confidence.

38 [2001] QB 967, at 1005. Similarly Keene LJ (at 1011) dismissed the point as "unsustainable", observing that there was "no reason why the photographs inherently could not be the subject of a breach of confidence." In Hellewell [1995] 1 WLR 804, at 807 Laws J commented that he had "no doubt that disclosure of a photograph may ... be actionable as a breach of confidence."

39 [2002] EMLR 371, at 373.

40 [2001] HCA 63, at para 42.

41 [2003] 2 WLR 80.

42 In Attorney General v Guardian Newspapers (No.2) [1990] 1 AC 109, at 282 Lord Goff observed that "the principle of confidentiality only applies to information to the extent that it is confidential. In particular, once it has entered what is usually referred to as the public domain (which means no more than that the information in question is so generally accessible that, in all the circumstances, it cannot be regarded as confidential) then, as a general rule, the principle of confidentiality can have no application to it." 
Generally speaking, examples of situations in which images are taken in breach of confidence prove easy to conceptualise. We imagine the paparazzo, with his telephoto lens or his hidden camera, observing from an unseen platform, snapping images of the famous and infamous engaged in acts of a private and personal nature on private property. ${ }^{43}$ One example might be the actress who chooses to sunbathe topless in the quiet seclusion of a private hotel; ${ }^{44}$ another might be the television presenter photographed in flagrante delicto in a London brothel. ${ }^{45}$ In both cases it is easy to comprehend how such photographs will be regarded as information carrying a necessary quality of confidentiality; in both cases injunctions were granted to prevent the publication of the images. Consider, however, the case of $A$ ( $A$ Child) v Newham $L B C$ in which photographs were taken on behalf of the Newham Borough Council of the claimant, a child who was attending a nursery run by the local authority. ${ }^{46}$ These photographs were subsequently used, somewhat insensitively, to front brochures advertising council services such as their Strategy for Children and any Young People who are Affected or Infected by HIV or AIDS. The parents of the child complained. The court considered that the photographs had been reproduced in breach of confidence and awarded damages in the sum of $£ 5,000 .{ }^{47}$ But what is it about the image of a child playing in a local nursery that warrants the tag of having the necessary quality of confidence about it? Similarly, a photographer for the Manchester Evening News took photographs of Jodie, the survivor of the operation to separate her from her conjoined twin Mary. These photographs were taken, from a public footpath outside the hospital grounds, of the child when she was in the hospital car park. Jodie's parents, the Attards, had previously agreed a deal, allegedly worth between $£ 350,000$ and $£ 500,000$, with the News of the World, the Mail on Sunday, Granada TV and Now Magazine for their exclusive story, including images of Jodie, and so secured an injunction to prevent the publication of the surreptitiously taken photographs. ${ }^{48}$ Again, this begs the question as to what actions 10-month old Jodie could have been engaged in that could be considered private or confidential in nature.

It might be suggested that the place in which both children were photographed constituted a significant factor in deciding that a breach of confidence was committed, in that the hospital car park and the local nursery represented quasi-private spaces. This, however, is not an entirely satisfactory explanation given that the courts have often indicated that an individual's actions are not necessarily of a private or personal nature simply

43 For an interesting essay on the development of the paparazzi and their place within contemporary society see Carol Squiers, "Class Struggle: The Invention of Paparazzi Photography and the Death of Diana, Princess of Wales" in Carol Squiers (ed.), OverExposed: Essays on Contemporary Photography (The New Press, New York, 1999), at 269.

44 Amanda Holden v Express Newspapers (2001) (unreported).

45 Theakston v MGN Ltd [2002] WL 45379.

46 [2002] WL 819950; see The Guardian, October 172001.

47 The courts had previously indicated that damages may be awarded for breach of an equitable duty of confidentiality; see Seager v Copydex [1967] RPC 349.

48 The Guardian, October 82001. 
because they are not performed in public. ${ }^{49}$ Alternatively the key factor could be the surreptitious nature of the photography, but again, this doesn't seem entirely convincing given the circumstances in the Newham Borough Council case - no paparazzo, no telephoto lenses, no hidden cameras. Rather, it appears to be the case that the judiciary seem willing to attribute a special significance to the photographic image and are prepared to intervene when that image is to be published and circulated contrary to the wishes of the subject. ${ }^{50}$ In Theakston the court was willing to endorse the publication of information concerning the fact that the television presenter went to a brothel, as well as a full account of the activities engaged therein (on the basis that there was no obligation of confidentiality between a prostitute and client unless specifically requested) but drew the line at the publication of photographs of the same, and yet, wherein lies the essential difference between this verbal and visual information? ${ }^{51}$ In his decision in Theakston Ouseley J observed that "[t]he courts have consistently recognised that photographs can be particularly intrusive and have showed a high degree of willingness to prevent the publication of photographs, taken without the consent of the person photographed but which the photographer or someone else sought to exploit and publish." He continued that the publication of the photographs would, in this case, "be particularly intrusive into the claimant's own individual personality." ${ }^{52}$

49 In $A$ v $B$ and $C$ [2002] EMLR 371, at 382, Lord Woolf observed that "[a]n activity is not private simply because it is not done in public." Similarly Gleeson CJ, in Australian Broadcasting Corporation [2001] HCA 63, commented that " $[\mathrm{t}]$ here is no bright line which can be drawn between what is private and what is not. Use of the term "public" is often a convenient method of contrast, but there is a large area in between what is necessarily public and what is necessarily private. An activity is not private simply because it is not done in public. It does not suffice to make an act private that, because it occurs on private property, it has such measure of protection from the public gaze as the characteristics of the property, the nature of the activity, the locality, and the disposition of the property owner combine to afford."

50 In this respect, one of the main reasons why Douglas and Zeta-Jones failed in their attempt to prevent the publication of the surreptitious photographs of their wedding was the fact that they had planned to publish similar photographs anyway; Keene LJ commented that "[i]n the present case, it is of considerable relevance that very widespread publicity was to be given in any event to the wedding very soon afterwards by way of photographs in "OK!" magazine;" see [2001] QB 967, at 1013.

51 My thanks to Dr George Pavlakos for pointing out to me that, regardless of the fact that the information conveyed is the same, the verbal and the visual differ in relation to the intensity of our interaction with, and knowledge of, that information.

52 [2002] WL 45379, my emphasis. Consider the following scenario: I go to a professional photographer to have a head and shoulders portrait of myself taken. On the way there something occurs to sully my mood and, as a result, the portrait shows me with a rather disinterested expression upon my face. Later I find out that the photographer was so taken with the photograph that he is to include it in the forthcoming national exhibition of his work (he rather pretentiously entitles it Portrait of the Human Condition). Leaving aside issues concerning breach of contract and copyright infringement, this would seem to be a rather clear case of a breach of confidentiality on the part of the photographer, as was the case in Pollard. This being the case, then the photograph (the information) would appear 
The nature of this distinction between verbal and visual information was recently revisited by the Court of Appeal in Campbell $v$ MGN Ltd. ${ }^{53}$ The claimant, Naomi Campbell, had complained of stories that had been printed in the Mirror newspaper in February 2001, concerning her drug addiction and subsequent treatment, alleging that reporting the details of her treatment involved a breach of confidence on the part of the Mirror Newspaper Group. The newspaper articles were accompanied by photographs that depicted Campbell leaving one of her meetings at Narcotics Anonymous, however the photographs were not drawn within the ambit of the argument as to the breach of confidence. ${ }^{54}$ At first instance Morland $\mathrm{J}$ held in favour of Campbell. He considered that reporting the details of her drug treatment amounted to a breach of confidence and rejected the respondents' argument

to have the necessary quality of confidentiality. Now, consider further: the reason why I was so surly and disaffected upon arriving at the photographers was because, on my way there, travelling by bus, the passenger sitting in front of me, just before getting off the bus, turned around and took my photograph without my permission. After getting off the bus he disappears around a corner leaving me with nothing but a bad mood and a surly expression. It later transpires that he too was a photographer of some national repute, and in his latest exhibition (opening coincidentally upon the same day as my portrait photographer's exhibition) he too has included the photograph of me (he rather unimaginatively calls his piece Disinterested man on the bus). Somewhat amazingly, this second image is almost identical to the first. Does this second, identical image lack the necessary quality of confidence in a manner in which the first photograph does not? If so, why is this the case?

53 [2003] 2 WLR 80.

54 Instead, it was argued that their publication amounted to a breach of the respondents' obligations under the Data Protection Act 1998 in that the photograph represented data of a sensitive and personal nature. Accepting that the photograph qualified as "sensitive personal data" in that it conveyed information as to Campbell's "physical or mental health or condition", Morland J ruled out the possibility that the defendants were exempt from liability under s.32 of the 1998 Act on the grounds that the wording of the section dealt only with "pre-publication processing." That being the case he considered that the defendant had acted in contravention of the First Data Protection Principle under s 4(4) in failing to deal with the data either fairly (in taking the photographs in a clandestine manner) or lawfully (in obtaining the details of her attendance at the meetings in breach of confidence). Moreover, he considered that the defendant had failed to meet any of the conditions set out in Sch 2 or Sch 3 of the 1998 Act, or to satisfy the requirements of para 3(1) of the Data Protection (Processing of Sensitive Personal Data) Order 2000 (SI 2000/417) in that the disclosure of the relevant details were not, in his opinion "in the substantial public interest." The Court of Appeal, in overturning this aspect of Morland J's decision, focused upon whether or not the s 32 exemption only applied up to the point of publication. Noting that "it would seem totally illogical to exempt the data controller from the obligation, prior to publication . . . but to leave him exposed to a claim for compensation . . . the moment the data had been published", the Court considered that the only meaning that would make sense would be to allow that s 32 applied "both before and after publication." Proceeding upon this basis, and considering the facts of the case, Lord Phillips held that, given that the details under consideration were "part of a journalistic package that it was reasonable to publish in the public interest", the defendant was entitled to rely upon the exemption within s 32 and so had not reproduced the photograph in breach of the obligations imposed under the 1998 Act; paras 120, 121, 137. 
that they were nevertheless free to publish the information on the grounds that they were exercising their right to freedom of expression in circumstances in which there was a clear public interest. Observing that the Human Rights Act 1998 was not to be used to "whittle away to any extent rights to respect for private life under Article 8 of the Convention", Morland $\mathrm{J}$ concluded that "[a]lthough many aspects of the private lives of celebrities and public figures will inevitably enter the public domain, in my judgment it does not follow that even with self-publicists every aspect and detail of their private lives are legitimate quarry for the journalist. They are entitled to some space of privacy." 55 Upon appeal, the decision was reversed.

In the Court of Appeal, although the photographs were not incorporated within the breach of confidence claim, there was some obiter discussion of the place of the public photograph within the action in general. Noting a distinction between infringement of privacy "as a species of breach of confidence" and infringement of privacy "as a free-standing tort" Lord Phillips MR observed that "[ $\mathrm{t}] \mathrm{he}$ photographs published by the Mirror were of a street scene. They did not convey any information that was confidential." The confidential information under consideration was that conveyed within the articles and the captions accompanying the photographs; the photographs in themselves added nothing, as they were merely supplementary to the written information. ${ }^{56} \mathrm{He}$ continued with the speculation that had Campbell sought to rely upon the photographs alone as the foundation of her action this would have involved her having to resort "to the free-standing tort of breach of privacy to make out her case." They may have been "invasive" but, in Lord Phillips" opinion, the photographs "did not convey confidential information." ${ }^{57}$ The fact that these photographs were of a public scene, a "street scene", seems to have been influential in guiding these comments and as such, his observations appear to dispose of the possibility of mounting an action for breach of confidence when the information under consideration involves an image taken of any given individual in an obviously public space.

Had Lord Phillips concluded his observations upon street photography at that point, his obiter comments might have operated to retard the trend that seems to have developed throughout the decisions discussed above. However, later in his judgment, in deciding as to whether the written information in this case had the necessary quality of confidence about it, and, while adopting the same test as Morland J but rejecting his conclusions, Lord Phillips doubted whether "a reasonable person of ordinary sensibilities, on reading that Miss Campbell was a drug addict, would find it highly offensive ... that the Mirror also disclosed that she was attending meetings of Narcotics

55 Paras 54-71.

56 Lord Phillips, at para 34, commented in the following terms: "[W]e consider that the publication of the photographs adds little to Miss Campbell's case. They illustrate and draw attention to the information that she was receiving therapy from Narcotics Anonymous. Insofar as publication of that information constituted a breach of confidence, the illustrations constituted an aspect of that breach that had potential relevance to the assessment of damages. Insofar as publication of that information was not a breach of duty, that position was not altered by the publication of the accompanying photographs."

57 Ibid at para 33 
Anonymous." 58 He continued that "[t]he reader might have found it offensive that what were obviously covert photographs had been taken of her, but that, of itself, is not relied upon as a ground of legal complaint." 59 The concession is an interesting one. Again, as was the case with the decision of Ouseley $\mathrm{J}$ in Theakston, Lord Phillips leaves open the possibility that the verbal information that Campbell was a drug addict leaving a particular therapy group, and the visual record of that information (the photograph), could be treated differently under an action for breach of confidence. The acceptance that a reasonable person might make such a distinction between the written and visual information (especially when captured in a covert manner) is an important admission in this regard. Moreover, it is an admission that colours what might fruitfully be taken from Lord Phillips' earlier comments in relation to the fact that the photograph was of a public scene. ${ }^{60}$ The Court of Appeal conceded that "the fact that an individual has achieved prominence on the public stage does not mean that his private life can be laid bare by the media", but set out that, underpinning their decision, and its accommodation of Article 8 and Article 10 rights, was the principle that "where a public figure chooses to make untrue statements about his or her private life, the press will normally be entitled to put the record straight." ${ }^{\prime 61}$ It is not just the fact that any individual had been photographed in public; rather, of significance was that it was Naomi Campbell, the self-publicising supermodel, who was photographed in the street. The concession that Lord Phillips admits, in relation to the reasonable reader's potential attitude to the publication of covert street photography, as well as the overt rhetoric of Ouseley $\mathrm{J}$ in Theakston, when married to the individual decisions concerning Jodie and Child A, arguably betray an emergent judicial attitude to the public dissemination of a private individual's image that signals potentially serious consequences for the work of any photographer operating within the public sphere. Moreover, the development is one that will arguably derive additional support from the attitude and decision of the European Court in Peck.

\section{CONCLUSION}

This article does not suggest that we have reached a point, similar to that in France and other legal jurisdictions, where private individuals do have a general right to control the dissemination of their image, even though they

58 Lord Phillips commented as follows (para 53): "Given that it was legitimate for the appellants to publish the fact that Miss Campbell was a drug addict and that she was receiving treatment, it does not seem to us that it was particularly significant to add the fact that the treatment consisted of attendance at meetings of Narcotics Anonymous."

$59 \mathrm{Ibid}$, at para 54.

${ }^{60}$ It is of interest to recall that the Mirror in reproducing the photographs had taken the step of pixellating the faces of those other individuals leaving the meeting at the same time as Campbell; para 32 ibid.

$61 \mathrm{Ibid}$, at paras 41 and 43 . This aspect of the decision accords with that part of the general guidance set out by Lord Woolf in $A \mathrm{v} B$ and $C$ pertaining to the diminished nature of the right of privacy that a public figure can expect to enjoy as a result of his public profile. 
have been captured on film in public. ${ }^{62}$ In Delahaye's work, he refers to the fact that he "stole" his metro photographs since it was against the law to take them - it was "forbidden." ${ }_{33}$ Should he engage in the same experiment on the London underground it is unclear as to whether his actions would be similarly "forbidden". All that has been suggested here is that, in the light of recent developments regarding the law of confidence, it is possible to conceive of an individual making use of an action in confidence to prevent the publication of such images, especially when taken in the necessarily covert manner in which Delahaye and others operate. ${ }^{64}$ Some might object that the courts would be slow to develop the common law action in such a fashion, but, given the special significance that the courts appear willing to attribute to the photographic image and its relationship with "the integrity of [a] claimant's personality", the argument remains to be made. Of late, drawing clear distinctions between that which is confidential and that which is non-confidential has become more problematic; the lines between private and public information, spaces and actions, stand revealed as chimerical, elastic, unknowable. ${ }^{65}$ In Douglas Keene LJ proffered the observation that "breach of confidence . . . is a developing area of the law, the boundaries of which are not immutable but may change to reflect changes in society, technology and business practice." ${ }^{\circ 6}$ Similarly, in Campbell Lord Phillips

62 For a recent review of those jurisdictions within which such rights subsist, see Michael Henry (ed), International Privacy, Publicity and Personality Laws, (Butterworths, London, 2001).

63 Henry notes that the right to protection of one's likeness under French law involves the right "to prohibit the production and distribution of an individual's likeness without the subject's consent". Nevertheless there are some judicially developed exceptions to this right: (1) When the image is incidental and was taken in a public place; (2) When it concerns a subject of a current event and is published soon after; (3) When it concerns the reporting of a trial; (4) When it concerns the likeness of a public figure in his public life. Ibid, at 152-53.

64 In Hellewell [1995] 1 WLR 804, at 807 Laws J observed that "[i]f someone with a telephoto lens were to take from a distance and with no authority a picture of another engaged in some private act, his subsequent disclosure of the photograph would, in my judgment, as surely amount to a breach of confidence as if he had found or stolen a letter or diary in which the act was recounted and proceeded to publish it. In such a case, the law would protect what might reasonably be called a right of privacy, although the name accorded to the cause of action would be breach of confidence." Lord Woolf, in $R$ v Loveridge (2001) EWCA Crim 973, commented that within the ambit of the right to respect for a private life "secret filming in a place to which the public has free access can amount to an infringement even where there is no private element to the events filmed. Secret filming is considered objectionable, because it is not open to those who are the subject of the filming to take any action to prevent it: BSC, ex p BBC [2000] 3 WLR 1327." In his earlier judgment in ex $p B B C$, at 1337-38, having observed that "we are in an area involving open textured concepts. An interference with privacy is not even like an elephant, of which it can be said it is at least easy to recognize if not define. The meaning of privacy can be influenced by the context in which it appears", Lord Woolf continued that "clandestine filming is objectionable. The fact that it is secret prevents those who are being filmed from taking any action to prevent what they are doing being filmed."

65 See for example the comments of Gleeson CJ in Australian Broadcasting Corporation v Lenah Game Meats Pty Ltd supra $\mathrm{n} 40$.

66 [2001] QB 967, at 1011. 
observed that " $[t]$ he courts are in the process of identifying, on a case by case basis, the principles by which the law of confidentiality must accommodate [our] Article 8 and the Article 10 rights." ${ }^{67}$ What is at issue here is the production of a newly modelled breach of confidence action capable of preventing indiscriminate exchange and display of public images captured in public spaces but which also appropriately balances respect for privacy and freedom of expression.

Consider, for example, recent work by Beat Strueli who takes urban portraits, with the use of a telephoto lens, rendering background details blurred and abstract, and capturing unknowing subjects engaged in moments of daily routine, but moments which betray often dramatic qualities of personal and private introspection. ${ }^{68}$ Similarly, in Philip-Lorca di Corcia's series, Heads, the photographer introduces theatrical lighting effects into photographs that are triggered by the movement of unwary passers-by tripping motion sensors linked to both camera and lights positioned some distance away. ${ }^{69}$ It is no longer inconceivable that the courts, if asked, would step in to prevent the unauthorised publication of such work, or indeed the work of any one of a number of other photographers working in a clandestine manner on the street. That the courts could, in theory, act to prevent such publication is one issue for consideration. Whether or not the courts should act to prevent such publication is another matter; there are clearly important social, cultural and legal considerations to weigh in the balance.

In the first place, adopting legal strategies that begin to function as de facto image rights represents a serious threat to the very existence of street photography, be it for the art gallery, for commercial publication or for photojournalism as a genre. As Geoffrey Batchen has established, the art of surveillance photography (that of "seeing without being seen") "has been a central tenet of the practice of photography throughout its history;" its influence and importance can be traced back in time through the work of numerous seminal figures such as Lazlo Moholy-Nagy, Bill Brandt, Erich Salomon and Walker Evans, right back to the very inception of the tradition, incorporating many of the images captured by the pioneer of British photography William Henry Fox Talbot. ${ }^{70}$ Di Corcia, in an earlier series of photographs, redistributed grant money that he had received to rent-boys, drug addicts and drifters inhabiting the Santa Monica Boulevard in Los Angeles in exchange for the opportunity to photograph them. Such an

67 [2003] 2 WLR 80, at para 43.

68 Examples of Strueli's work, as well as those of a wide range of other street photographers, can be found in Open City: Street Photographs since 1950 (MOMA Oxford/Hatje Cantz Publishers, 2001).

69 Philip-Lorca di Corcia, heads, (PaceWidenstein/Steidl, New York, 2001).

70 Batchen describes how Fox Talbot was "in the habit of leaving his small camera obscura lying around the grounds of his estate to allow for the long exposure times necessary for his photogenic drawings. This detached prosthesis of his own eye would record the outlines of his house, but also anything else that might venture into its field of vision and hang around long enough." He also recounts that Fox Talbot's wife Constance referred to his camera as a "mousetrap", a nickname that referred to both its small size as well as its hidden, and dangerous capacity for capturing subjects unawares. See Geoffrey Batchen, "Guilty Pleasures", in Thomas Y Levin, Ursula Frohne, Peter Weibel (eds), Rhetorics of Surveillance from Bentham to Big Brother (MIT Press, 2002). 
approach would no doubt become the norm rather than the exception. Conceding the prospect that photographers necessarily negotiate with those they photograph in public spaces (either before or after the fact of the photograph) would not only fundamentally shift the nature of the relationship between photographer and subject, but would introduce unwarranted and unwanted aspects of control and censure into a field of photography that seeks to address questions of the spontaneous, the real and the true. It may be the case that, in relation to the press photographer at least, the consequences of a more robust action for breach of confidence would be ameliorated by the special weight that the courts attribute to the importance of maintaining a free and democratic press ${ }^{71}$ but even this has its limitations when considering the interests of the private individual; moreover, there is no guarantee that similar considerations will necessarily be extended to the creators of culturally significant works of art.

More worrying, however, is the clear danger of twisting the traditional action of breach of confidence out of all recognition. In this regard the Manchester Evening News case suggests a radical break with the function that confidentiality serves in relation to the dissemination of personal and private information. In his exploration of privacy and publicity rights, Peter Jaffey recently commented upon the importance of drawing a distinction between the right to prevent harm and rights of ownership, suggesting that claims pertaining to breach of confidence can take either form. ${ }^{72}$ When dealing with commercially exploitable trade secrets, confidentiality operates in much the same manner as any other intellectual property right, and the rights of the confider are akin to ownership. By contrast, when considering situations involving the disclosure of sensitive information, confidentiality functions to protect against "embarrassment, self-consciousness or humiliation;" in appropriate circumstances, it operates as a "proto-tort of privacy" designed to protect against harm to the claimant. ${ }^{73}$ This latter form of confidence does not and should not serve any proprietary interests. Simon Brown LJ made this point explicitly in ex $p$ Source Informatics, which concerned the information that customers provided pharmacists when retrieving their prescriptions, in stressing the fact that in this area the concern of the law:

$[\mathrm{I}] \mathrm{s}$ to protect the confider's personal privacy. That and that alone is the right at issue ... The patient has no proprietorial claim to the prescription form or to the information it contains. Of course he can bestow or withhold his custom as

71 See for example the comments of Lord Woolf in $A \vee B$ and $C$ [2002] EMLR 371, at 381: "The fact that if the injunction is granted it will interfere with the freedom of expression of others and in particular the freedom of the press is a matter of particular importance . . . Any interference with the press has to be justified because it inevitably has some effect on the ability of the press to perform its role in society. This is the position irrespective of whether a particular publication is desirable in the public interest. The existence of a free press is in itself desirable and so any interference with it has to be justified ... The courts must not ignore the fact that if newspapers do not publish information which the public are interested in, there will be fewer newspapers published, which will not be in the public interest."

72 Peter Jaffey, "Privacy, Publicity Rights and Merchandising: Hello!" in E Barendt \& A Firth (eds) Yearbook of Copyright and Media Law, Vol. VI (OUP, 2002) 21.

73 Ibid, at 23-24. 
he pleases ... [b]ut that gives the patient no property in the information and no right to control its use provided only and always that his privacy is not put at risk. ${ }^{74}$

Jaffey comments that "[d]amage to the reputation of an individual (or intrusion on his privacy) is not normally understood to be a form of financial or economic loss," 75 and yet this is exactly what seemed to influence the approach of the court in the Manchester Evening News case. The fact that Jodie's parents, the Attards, had secured a six-figure publication deal for their story including exclusive pictures of their daughter, certainly appears to have influenced the decision. This is not about the prevention of harm and the protection of the child's privacy, so much as the first steps upon the road to establishing a nascent right of publicity, that is, a general right that operates to protect the commercial exploitation of one's image, as an outgrowth of a newly modelled common law action that is primarily concerned with securing certain aspects of the private life of the individual. ${ }^{76}$ Such a development is to be strongly resisted; as Jaffey observes: "[I]t would be anomalous if the right of privacy in the Convention encompassed a right of publicity or merchandising right." 77 Delahaye in his introduction to L'Autre remarks that "our image, this worthless alias of ourselves, is everywhere without us knowing it" and, given this reality, he asks: "How and why can it be said to belong to us?" The point however is not so much how our image can be said to belong to us; legally, it demonstrably can. Rather, the question should be, can we tolerate the realities of a world in which ownership, control and circulation of the public image resides in the hands of the private individual?

74 [2001] QB 424, at 440.

75 Supra $\mathrm{n} 72$ at 25.

76 Clear parallels can be drawn between these embryonic developments within the UK and the American experience in which rights of publicity developed as an outgrowth of the right to privacy. See for example: Melville B Nimmer, "The Right of Publicity" (1954) Law \& Contemp. Probs 203; William L Prosser, "Privacy" (1960) Cal.LR 383; Harold R Gordon, "Right of Property in Name, Likeness, Personality and History" (1960) NwULR 553; Oliver R. Goodenough, "The Price of Fame: the Development of the Right of Publicity in the United States" (Parts 1 and 2) [1992] EIPR 55 and 90; Michael Madow, "Private Ownership of Public Image: Popular Culture and Publicity Rights" (1993) Cal.LR 127; Oliver R. Goodenough, Privacy and Publicity: Society, Doctrine and the Development of the Law (Intellectual Property Institute, 1996). An interesting point of difference between the historical development of the law within the US and the way in which these nascent publicity rights appear to be emerging within the UK is that, while the American tradition represented a response to the inability of the public celebrity to restrict the unauthorized commercial exploitation of his or her image and personality, within the UK, such publicity rights would, ironically, primarily function to protect the economic interests of the private individual. In this regard it is interesting to contrast the attitude of the Court of Appeal in Douglas v Hello! where it was willing, on the balance of convenience, to allow publication of the pictures and leave the claimants to pursue appropriate damages (or an account of profits) from the defendants should their action succeed at the trial stage, with that of the court in the Manchester Evening News decision, which ostensibly addressed the same fundamental concern of safeguarding the commercially lucrative image.

77 Supra n 72, at 27. 
